\title{
Transfer of managerial models by foreign industrialists to South Russia in the late 19th - early 20th century
}

Transfer modelów zarzqdzania przez zagranicznych przemysłowców na teren południa Rosji u schyłku XIX i na poczq̨tku XX wieku

\section{STRESZCZENIE:}

Niniejsza praca prezentuje badania nad procesem transferu na grunt rosyjski modelu zarządzania i praktyk stosowanych w przemyśle przez cudzoziemców w okresie przedsowieckim na podstawie rozwoju przemysłu, oficjalnych statystyk rządowych i niepublikowanych materiałów z lokalnych archiwów ukraińskich.

Słowa kluczowe: industrializacja, rewolucja zarządzania, imperium rosyjskie

Contents: I. Problem statement. - II. The development of modern business in Russia. - III. Transfer and adaptation of managerial practices. - IV. Transfer and adaptation of managerial models. - V. Conclusions.

\section{PROBLEM STATEMENT}

From the mid-1880s, the beginning of industrialization in the Russian Empire, Russian industry experienced a rapid development. The growth rate in this period exceeded even that of the leading industrial countries ${ }^{1}$. By 1913, the share of industry in the national product increased up to $32 \%{ }^{2}$. This lead to an essential transformation of the economic structure: Russia turned from an agrarian country into an agrarian-industrial one.

${ }^{1}$ A. Gerschenkron, The Rate of Growth in Russia: The Rate of Industrial Growth in Russia Since 1885, "The Journal of Economic History" 1947, nr 7, s. 156

2 P. Gregory, Before Command: An Economic History of Russia from Emancipation to the First Five-Year Plan, Princeton-New Jersey 1994, s. 132. 
The development of modern business accompanied by a managerial revolution was one of the most significant changes induced by the industrialization in all developed countries in the late $19^{\text {th }}$-early $20^{\text {th }}$ century. Small family firms were replaced by large-scale enterprises administered by a hierarchy of salaried managers as the primary agent of organizing production and distribution. In the late $19^{\text {th }}$ century managers became important actors in a range of economic and social relations. After the second industrial revolution the new element in the system of labor relations appeared: the owner-worker binary model of labor organization was replaced by the new model of owner-manager-worker. This is why it seems to be logical to assume, that management and the layer of managers (among them many foreigners) emerged as an important economic and social factor in the development of modern, large-scale business activity and in the modernization of society in general in Russia as well.

The prominent role played by foreign investment and industrial technologies in the Russian industrialization process has been known for scholarship both in Russia and abroad. Scholars, however, have paid surprisingly little attention to the history of managerial systems and managerial revolution in the Russian Empire, including transfer of managerial models by foreign entrepreneurs.

The issue has been addressed perfunctorily, mainly in the framework of case studies focusing on individual enterprises ${ }^{3}$. Apart from one publication about the salaried managers in Russia in the $19^{\text {th }}$ and $20^{\text {th }}$ centuries $^{4}$ and the research project "The managers of enterprises in Russia in the early $20^{\text {th }}$ century: Historical and anthropological analysis" (director - Irina Shilnikova, 2008-2010), I cannot provide any other example for an overview of managerial history in Russia. Both of these studies are based mainly on materials from the Central Industrial Region of Russia and focused mainly on managers but not managerial systems. That is why I consider it highly relevant to address the history of operations management and managerial revolution in South Russia.

\footnotetext{
${ }^{3}$ For example, the monograph devoted to the study of incentives for workers of textile materials on the pre-revolutionary Russia was based on studying two major companies - Manufactures Association N.N. Konshina and the Association of Yaroslavl large manufactory. Less than five pages (68-72) were devoted to the management of the large manufactory of the Association of Yaroslavl, in which the authors tried to reconstruct the managerial scheme and described briefly the incumbency of certain officers (И.И Бородкин, Т.Я. Валетов, Ю.Б. Смирнова, И.В. Шильникова, «Не рублел единылм»: Трудовые стихуль рабочих-текстильщиков дореволюциионной России, Москва 2010.

${ }^{4}$ Ю.А. Петров, Е. Савинова, М. Золотарев, Наемные управляющие в России: опьы бизнес-элиты XIX-XX веков, Москва 2007.
} 
This paper investigates how foreign industrialists contributed to the transfer and implementation of managerial models and practices to South Russia in the period of pre-Soviet industrialization, how the social, economic and cultural environment reacted to these changes, and how the applied management strategy was impacted by the responses. In particular, the aim is to answer such questions as if we can attribute - using A. Chandler's term - the appearance of the "Visible hand" in Russia mainly to the foreigners, i.e. if we can evaluate the managerial revolution as a phenomenon that was mostly imported from the West? How can we define, through the prism of assessing the role of foreign businesspersons, the peculiarities of the creation of modern industrial enterprise and the appearance of professional manager class in the Russian Empire? How were the Western managerial ideas and practices adapted to Russian reality?

The research is focused on the geographical area called Southern Industrial Region in the Russian Empire. This included the provinces of Ekaterinoslavskaya, Khersonskaya, Tavricheskaya and Kharkovskaya ${ }^{5}$. By the end of the $19^{\text {th }}$ century - besides such centers as Moscow and Petersburg - this region became the main area and channel for the transfer and adaptation of Western European models of industrial production, having outrun the Ural Region in volumes, rates and innovations.

The chronological framework covers the decades between 1880 and 1918: from the end of the first industrial revolution in Russia to the time of the mass-nationalization of enterprises.

The present research is based on the analysis of industrial censuses and further official statistics, as well as unpublished sources housed in local Ukrainian archives providing information for case studies.

The Chinese philosopher Confucius said that the most difficult thing among all is to find a black cat in a dark room, especially if there is no cat. The researcher of operations management in Russia can easily feel as if he was searching for such a cat. I was working with the manufacturing documentation of many enterprises in Ukrainian archives and the amount of direct information I found about managerial models applied in particular plants and factories was very little. Job descriptions for managers or labor contracts only sporadically occur. It is possible, however, to reconstruct the structure of management by studying "indirect" documents such as

${ }^{5}$ It comprised also a part of the Don Host Oblast (now in the Russian Federation). After collecting material for analysis, I will include this region too. 
financial statements containing bills of payed salaries. Based on such documents it can be assumed that while top-managers focused exclusively on administrative matters, middle- and low-level managers used to combine engineering responsibilities with managerial ones and they were employed primarily as engineers.

Another possible explanation for the weak reflection of the managerial element in the documents is the fact that the problem of effective management by itself appeared not earlier than in the late $19^{\text {th }}$ and early $20^{\text {th }}$ century. In the preindustrial and industrial era manual workers dominated. Managers constituted only a small percentage of the total number of employees, and their work was considered as a priori effective, even if it was not ${ }^{6}$.

Turning to the above mentioned indirect sources, one can apply a method similar to the one formulated for discovering planets in astronomy based on Doppler spectroscopy. According to this method, smaller object (such as an extrasolar planet) orbiting a larger object (such as a star) could produce changes in the position and velocity of the latter as they orbit their common center of mass.

The same holds true for management history: it is possible to address the topic based on the history of the development of modern business, which is satisfactorily represented in the sources. According to the theory of management revolution, the development of modern business enterprises determined the development of modern management. Consequently, it is important to answer the questions whether traditional small family firms were replaced by large-scale enterprises administered by a hierarchy of salaried managers in Russia. If yes - when, and what kind of role foreigners played in this process?

\section{THE DEVELOPMENT OF MODERN BUSINESS IN RUSSIA}

Alfred Chandler, in his theory of managerial revolution, distinguished two types of entrepreneurship: traditional and modern one. According to his definition, modern business has two specific characteristics: it contains many distinct operating units and it is managed by a hierarchy of salaried executives. Each unit has its own administrative office administered by a full-time salaried manager, and its own set of books and accounts. Thus, in theory, each unit could operate as an independent enterprise. In contrast, the traditional firm consisted of one single unit. The shop, factory, bank, or transportation line was operated by an individual or a small num-

${ }^{6}$ П.Ф. Друкер, Эницклопедия менеджмента, перевод с английского языка, Москва 2004, s. 234. 
ber of owners from a single office. Normally this type of firm was focused on the production of one product type, and operated in one geographic area ${ }^{7}$.

Contemporary publication of lists of plants and factories (so called "Lists of plants and factories") created on the basis of industrial censuses and other statistical surveys provide information on the proportion of different types of enterprises, the time of their foundation, and on the own$\mathrm{ers}^{8}$. This is enough to find out whether traditional family enterprises were replaced by modern ones, and if yes, when and in what extent.

By entering the data from the industrial census of manufacturing in 1900 into a relative database system and analyzing it, the following can be concluded (Table 1): among the plants and factories located in the four South Russian provinces (a total of 1290) in 1900 85\% belonged to single and joint owners. The share of corporative ownership is less than $15 \%$. Though by the beginning of the $20^{\text {th }}$ century multiunit business enterprises owned by stock-companies started to replace gradually the small traditional enterprise, still the traditional individual (family) entrepreneurship was the dominant form. Most industrial enterprises were concentrated in the hands of a sole owner or co-owners, but the largest companies were possessed by stock companies, and the lion's share ${ }^{9}$ of the production and workers was focused there.

The first stock companies appeared in the Russian Empire under the rule of Peter the Great and in the late $18^{\text {th }}$-early $19^{\text {th }}$ century a legislative provision of stock companies' activities took place. Still, before the beginning of the industrialization there were only a few joint-stock companies in the industrial business. Most of them appeared in South of Russia after 1890 (see Figure 1).

${ }^{7}$ A. Chandler, The Visible Hand: The Managerial Revolution in American Business, Harvard 1977.

${ }^{8}$ В.Е. Варзар, Список фабрик и заводов Европейской России, С.-Петербург 1903; idem, Список фабрик и заводов Российской Июперии, С.-Петербург 1912; „Вестник, финансов и торговли", 1910, Список фабрик и заводов России. 1910 2. По официальнылм данным фабричного, податного и горного надзора; А.К. Езиоранский, Фабрично-заводские предприятия Российской империи, С.-Петербург 1909; Д.П. Кандауров, Фабрично-заводские предприятия Российской империи (исключая Финляндию), Петроград 1914.

${ }^{9}$ Though data in Table 1 show that the share of stock companies in the production output was about $25 \%$, these materials, based on industrial census in 1900 essentially understate the share of joint-stock companies. According to the opinion widespread in the scholarly literature only small businesses were not taken into account when compiling the „Lists of Plants and Factories”. My comparison of lists from various years have however revealed that the largest blast-furnace smelters were omitted for some reason from the "Lists ..." from 1900. If at least three of the largest plants are included into the calculations, industrial stock companies appear to be the leading ones in terms of production and of the number of workers. 
Table 1. Owners of industrial enterprises in South Russia in 1900.

\begin{tabular}{|l|r|r|c|r|r|r|}
\hline \multirow{2}{*}{ Type of the ownership } & \multicolumn{2}{|c|}{ Enterprises } & \multicolumn{2}{c|}{ Production } & \multicolumn{2}{c|}{ Workers } \\
\cline { 2 - 7 } & & $\%$ & million rubles & $\% \%$ & Thousands & $\% \%$ \\
\hline Single and joint owners & 1095 & 84,9 & 116,2 & 43,4 & 50,9 & 40,8 \\
\hline Partnership & 55 & 4,3 & 59,7 & 22,3 & 34,7 & 27,8 \\
\hline Trading houses & 41 & 3,2 & 28,3 & 10,6 & 5,6 & 4,5 \\
\hline Stock companies & 93 & 7,2 & 63,3 & 23,6 & 33,3 & 26,7 \\
\hline Others & 6 & 0,5 & 0,1 & 0,1 & 0,3 & 0,2 \\
\hline Total & 1290 & 100,0 & 267,6 & 100,0 & 124,9 & 100,0 \\
\hline
\end{tabular}

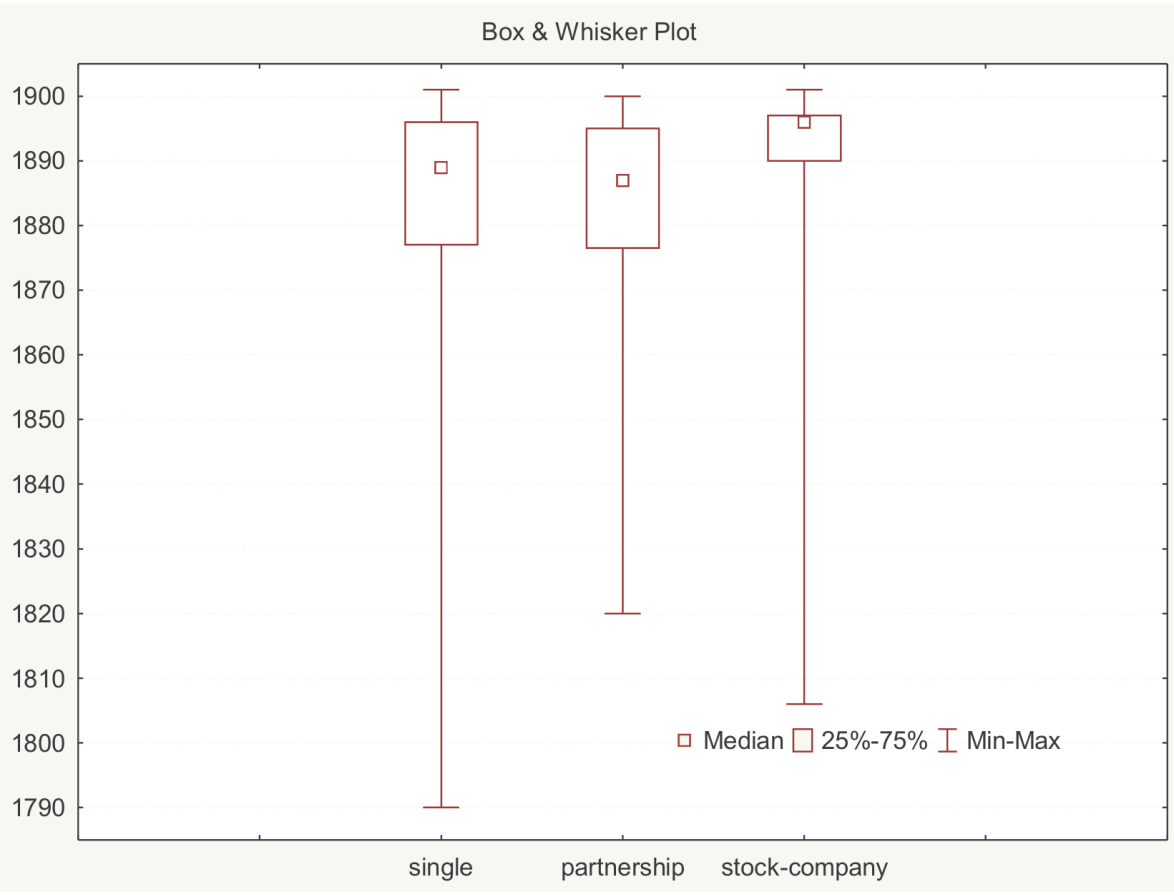

Figure 1. Chronological distribution of the foundation of those enterprises in South Russia that existed in 1900

There were examples of transforming traditional enterprises into modern ones, such as one of the largest iron-mechanical plant in the city of Elisavetgrad in Khersonskaya province. It was founded in 1875 by British citizens Robert and Thomas Elvorti. In the factories' lists from 1900 
the plant appeared as co-owned property, but in 1910 and 1913 as a stock company. Its annual output increased from 0,5 million rubles up to 5 millions by 1900, and the number of workers from 559 to $2000^{10}$.

In most cases however, stock companies in Russia owning industrial enterprises were founded as completely new enterprises without any precedents. It can be concluded that the formation of modern business and, as a consequence, managerial revolution took place in two streams: 1) through the evolution of the traditional family business into corporative ones and 2) founding stock companies by shareholders from "outside". It could be both Russian and foreign banks, foreign industrial companies, private businesses.

The development of stock capital led to a new diversified type of ownership and its separation from the management. The average size of corporative enterprises was 358 workers in contrast with the 45 workers of single and partnership-owned factories (Table 2).

Table 2. Number of workers per enterprise in South Russia in 1900.

\begin{tabular}{|l|r|r|r|r|r|c|}
\hline & Valid N & Mean & Median & Mode & $\begin{array}{c}\text { Lower } \\
\text { Quartile }\end{array}$ & $\begin{array}{c}\text { Upper } \\
\text { Quartile }\end{array}$ \\
\hline Single and joint ownership & 1095 & 45 & 24 & 12 & 13 & 45 \\
\hline Partnership & 55 & 295 & 145 & 400 & 30 & 420 \\
\hline Stock companies & 93 & 358 & 120 & 85 & 70 & 447 \\
\hline
\end{tabular}

Owners were not able to manage directly such a large group of people and stock company management acquired a professional character. Stock companies were more attracted by the technology industry, which sounds fairly reasonable, as building machine and metallurgy plants required large-scale long-term investment, usually not possessed by a sole entrepreneur. The solution lied in associating capital, technology, and management.

Such enterprises were characterized by a complex structure that demanded a hierarchy of salaried executives - professional managers. Based on lists of office workers stored in archival collections it is possible to reconstruct the structure of some particular enterprises. For example, the managerial structure of the Kharkov Locomotive Plant in 1916 - one of the largest plants in the region - was very complex, with departments, subdepartments and a hierarchy of professional managers. Each unit within the

${ }_{10}$ В.Е. Варзар, Список фабрик и заводов Европейской России, С.-Петербург 1903; Д. П. Кандауров, op.cit. 
plant had its own administrative office, some of them were even housed separately from the main buildings of the plant. Theoretically each could operate as an independent business enterprise ${ }^{11}$.

Considering the structure of the Kharkov Locomotive Plant and some other major companies we can say that by the beginning of World War I there existed modern enterprises in South Russia, which were characterized by a standard functional division of production: research and development, production, marketing, finance and accounting.

The joint-stock form of entrepreneurial activity arrived to Russia as an already fully formed institution after several centuries of development by European lawyers and merchants ${ }^{12}$. The adoption of this type of business organization by itself can be considered as a transfer of Western innovation. The following section will investigate further the role played by the "foreign factor" in the process of managerial revolution.

TRANSFER AND ADAPTATION OF MANAGERIAL PRACTICES

First of all it is important to find out how many foreign operations managers were working in the Russian Empire. According to researcher John MacKay, who studied thoroughly the archives of foreign companies working in Russia, a large number of foreign entrepreneurs were present in Russia. They copied the structure and the principles of management of the Western companies ${ }^{13}$, and spent significant amounts for administrative and engineering services. In John MacKay's opinion, the explanation for this was that the main advantage of employing a foreign manager over a Russian one lied not only in the higher professional level of the former, but in his superiority in the field of ethics. Foreign managers were often described as persons for whom the administration of a public corporation was a profession, not a "fief to be plundered"14.

Based on the analysis of memoirs however, the general perception of the level of Russian dishonesty appears to be overestimated. For example, mining engineer Alexander Fenin wrote: “... among South Russian engineers, professional ethics required irreversible loyalty to the owner. Throughout my long career, when I was in touch with hundreds of mining engineers whom I

${ }^{11}$ State Archives of Kharkov Oblast, Russian locomotive and mechanical society, List of persons employed during the 1916 calendar year in the service of Russian locomotive and mechanical company.

12 В.И. Бовыкин, Н.Н. Грушина, И.А. Дьяконов, Иностранное предпринимательство и заграничные инвестиции в России: Очерки, Москва 1997, s. 87-88.

${ }^{13}$ J.P. McKay, Pioneers for Profit: Foreign Entrepreneurship and Russian Industrialization. 1885-1913, Chicago 1970, s. 143.

${ }^{14}$ Ibidem, s. 177. 
observed under everyday conditions, I never came across dishonest people, with only one or two exceptions. Such people immediately became social outcasts"15. Similar illustrations can be found in many other memoirs too, like in that of Eduard Kriger-Voinovsky, the Minister of Railways of Russia: "cases of dishonesty among the management and employees of the railway were rare"16.

Some Russian engineers explained the dominance of foreign managers by the necessity "to protect the secrecy of production"17.

Furthermore, if turning to the actual numbers, it appears that the share of foreigners among all operations top-management employees in South Russia was not that significant. According to the approximate data collected by the Department of Trade and Manufactures of the Ministry of Finance, in the climax of the Russian industrialization the proportion of foreign top-managers in South Russia did not exceed 10\%. Although in high-tech production, such as iron-making and machinery building, it increased up to $28 \%$, most of the managers were Russian even there (see Table 3).

Table 3. The ratio of Russian and foreign operations top-managers in $1900^{18}$

\begin{tabular}{|c|c|c|c|c|c|}
\hline \multirow[b]{2}{*}{ Provinces } & \multicolumn{2}{|c|}{ Russians managers } & \multicolumn{2}{|c|}{ Foreign managers } & \multirow[b]{2}{*}{ 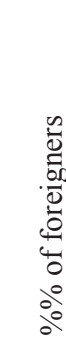 } \\
\hline & 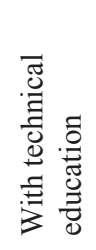 & 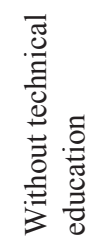 & 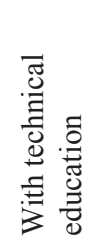 & 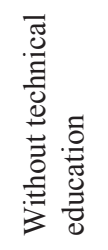 & \\
\hline Ekaterinoslavskaya & 14 & 324 & 13 & 17 & 8,2 \\
\hline $\begin{array}{l}\text { Including iron-making and machinery } \\
\text { building plants }\end{array}$ & 13 & 34 & 8 & 8 & 25,4 \\
\hline Don Host Oblast & 25 & 1229 & - & 6 & 0,5 \\
\hline $\begin{array}{l}\text { Including iron-making and machinery } \\
\text { building plants }\end{array}$ & 11 & 2 & 1 & - & 7,1 \\
\hline
\end{tabular}

${ }^{15}$ A.I. Fenin, Coal and Politics in Late Imperial Russia. Memoirs of a Russian Mining Engineer, Illinois 1990, s. 44.

16 Э.Б. Кригер-Войновский, Записки инженера: Воспоминания, впечатления, мысли о революичии, Москва 1990, s. 40-41.

${ }^{17}$ И. П. Бардин, Жизнь инженера, Nowosybirsk 1939.

${ }^{18}$ Calculated by me, based on: Свод данных о фабрично-заводской промыиленности в России за 1890 год, С.-Петербург 1893. 
ciąg dalszy tab. 3

\begin{tabular}{|l|r|r|r|r|r|}
\hline Tavricheskaya & 3 & 241 & 3 & 17 & 7,6 \\
\hline $\begin{array}{l}\text { Including iron-making and machinery } \\
\text { building plants }\end{array}$ & 2 & 37 & 1 & 8 & 18,8 \\
\hline Kharkovskaya & 23 & 322 & 9 & 13 & 6,0 \\
\hline $\begin{array}{l}\text { Including iron-making and machinery } \\
\text { building plants }\end{array}$ & 4 & 4 & 5 & 1 & 42,9 \\
\hline Khersonskaya & 45 & 341 & 50 & 70 & 23,7 \\
\hline $\begin{array}{l}\text { Including iron-making and machinery } \\
\text { building plants }\end{array}$ & 7 & 10 & 10 & 5 & 46,9 \\
\hline Totally: South of Russia & 37 & 87 & 25 & 22 & 27,5 \\
\hline $\begin{array}{l}\text { Including iron-making and machinery } \\
\text { building plants }\end{array}$ & 957 & 16717 & 417 & 903 & 6,9 \\
\hline European Russia & 1199 & 20843 & 525 & 1199 & 7,3 \\
\hline Russian Empire & & 75 & 123 & 7,2 \\
\hline
\end{tabular}

The largest iron-making and machinery plants, however, were mostly managed by foreigners - this can be an explanation for the perception of the dominance of foreign managers' manifest in some sources. Nevertheless, in many cases even if the director of the plant was Russian, he had been educated abroad. A characteristic example is that of one of the most outstanding Russian engineers, the top-manager Aleksey Goryainov. Before being appointed to the position of the director in the Alexandrovsky South Russian plant in Ekaterinoslav (1887), he attended courses in Belgium and France. The director of the Kharkov Locomotive Plant, Pavel Rizzoni visited the machine building factories of Usines Bouhey and The Société Alsacienne de Constructions Mécaniques in France in 1895 prior to launching the Kharkov plant ${ }^{19}$.

The main aim of such trips was to learn about innovations in metallurgy and engineering, but also to get acquainted with modern managerial approaches. Russian engineer Ivan Bardin, who spend more than year in the USA as a simple worker in the early $20^{\text {th }}$ century, confessed that "In America I got acquainted with the large-scale mechanized production of iron and steel, with the new open-hearth, domain and rolling mills, saw absolutely new

${ }^{19}$ Государственный областной архив Харьковской области, Совет правления Русского паровозостроительного и механического общества, Протоколы заседания Совета от 31 августа 1895 года. 
mechanized metallurgical process in the USA. America has expanded my technical horizon, gave me the knowledge how to run the affairs of a large factory; how to organize machinery and tractor production in a new way" 20 .

The most important question is whether factories managed by foreign managers proved to be more effective than those managed by Russians. Unfortunately there are almost no direct data on this issue. It is possible however to estimate the effectiveness from indirect information, which I will do taking the group of metalworking enterprises in South Russia as an example. Table 4 shows some average data indicating the effectiveness of metalworking plants grouped according to the structure of ownership in 1908, 1910 and 1913.

Table 4. Effectiveness of operations' management in metalworking enterprises in the South Russia ${ }^{21}$.

\begin{tabular}{|c|c|c|c|c|c|c|}
\hline & $\begin{array}{l}\text { Pro- } \\
\text { duc- } \\
\text { tion, } \\
\text { roubles } \\
(* 000)\end{array}$ & $\begin{array}{l}\text { Workers } \\
\text { per en- } \\
\text { terprise }\end{array}$ & $\begin{array}{l}\text { Produc- } \\
\text { tion per } \\
\text { worker }\end{array}$ & $\begin{array}{l}\text { Engine } \\
\text { power } \\
\text { (hp) per } \\
\text { enterprise }\end{array}$ & $\begin{array}{l}\text { Engine } \\
\text { power } \\
\text { (hp) on } \\
\text { the } 10 \\
\text { workers }\end{array}$ & $\begin{array}{c}\text { Engine } \\
\text { power }(\mathrm{hp}) \\
\text { at } 10,000 \\
\text { roubles of } \\
\text { production }\end{array}$ \\
\hline \multicolumn{7}{|c|}{1908} \\
\hline Russian owners & 57,6 & 47,1 & 1190,1 & 29,7 & 5,5 & 7,3 \\
\hline Foreign owners & 104,9 & 72,7 & 1210,2 & 21,2 & 3,7 & 5,7 \\
\hline Stock companies & 1593,7 & 723,6 & 1962,1 & 802,0 & 9,1 & 4,1 \\
\hline \multicolumn{7}{|c|}{1910} \\
\hline Russian owners & 73,9 & 50,0 & 1450,1 & 23,7 & 5,3 & 5,1 \\
\hline Foreign owners & 130,7 & 66,8 & 1576,9 & 22,5 & 5,1 & 4,2 \\
\hline Stock companies & 5657,0 & 1858,2 & 2430,2 & 6403,6 & 19,7 & 7,3 \\
\hline \multicolumn{7}{|c|}{1913} \\
\hline Russian owners & 144,3 & 120,1 & 1377,7 & 36,2 & 2,8 & 2,5 \\
\hline Foreign owners & 309,4 & 147,5 & 1720,6 & 35,8 & 2,5 & 2,0 \\
\hline Stock companies & 4676,1 & 1689,1 & 2873,6 & 6158,6 & 19,2 & 7,2 \\
\hline
\end{tabular}

${ }^{20}$ И.П. Бардин, op.cit.

${ }^{21}$ Calculated by me on the basis of "Lists of Factories and Plants" for the respective years. 
Stock companies were almost twice more efficient in using labor and engine as compared to single-owned enterprises. An interesting result is that single-owned companies belonging to (and managed by) Russians show no difference in efficiency from those managed by foreigners. This implies that there must have been no considerable difference in their managerial practices. It is difficult to tell however, if it were the foreign entrepreneurs who adapted to the Russian conditions or the Russian adopted quickly the Western ${ }^{22}$ innovations.

In the case of stock companies it is hardly possible to separate and compare "pure" Russian or foreign ones, because even if the company was registered as Russian, it could be foreign in every other respect. The "Nikopol-Mariupol Mining and Metallurgical Society" can be referred to as a characteristic example for this. It was established in Russia, and its board of administration was Russian too. Though the stock-company was founded in Russia, it was initiated by a German citizen, Adolf Rodshtein and an American, Edmund Smith ${ }^{23}$. In 1914 the fixed capital totaled 15.4 million rubles, 4 million from which was possessed by Frenchmen, the share of Belgian measured 3 million, and 3 million was the share of German capital ${ }^{24}$. Thus, the Society was formally Russian, but its foundation was initiated by foreign businessmen, it was based on foreign capital. The entire equipment and engineering came from abroad as well: in 1896 a complete steel plant was transported to Nikopol from the United States, and it was launched under the supervision of American engineers. The neighboring plant called "Russian Providance" of the Mariupol Mining and Smelting Company (founded 1896, Belgium) had its engineering based on American production standards, equipment and technologies ${ }^{25}$. Most of the largest metallurgical plants relied on the skills of foreign specialists they employed.

Some were, however, managed by Russias, but even in these cases they utilized Western approaches, as it happened in one of the largest Russian factories, the Alekasandrovskiy South-Russian Plant in Ekaterinoslav

\footnotetext{
${ }^{22}$ As $75 \%$ of foreign single-owners were German and Austrian, we can consider them as bearers of Western managerial models.

${ }_{23}$ Устав Никополь-Мариупольскаго горнаго и металлургическаго Общества: утвержден 10 мая 1896 года, С.-Петербург 1876.

${ }^{24}$ В.А. Дмитриев-Мамонов, Указатель действующзих в империи акциионерных предприятий и торговых домов. Сост. по данными, извлеч. из материала Ото. торговли, Особ. канцелярии по кредит. части и Деп. ж.-д. дел М-ва фин. Сведения об облигациях сост. Особ. канцелярией по кредит. части. Сведения о торговых домах сост. по офии. данныл учреждений М-ва вн. Дел, С.-Петербург 1905, s. 993.

${ }^{25}$ State Archives of Donetsk Oblast., "Russian Providans" Mariupol Mining Metallurgical Society of station Sartana, U.S. specifications of metal production.
} 
(Bryansk Rail-rolling, lironworks and Mechanical Plant Society). Russian director Aleksey Goryainov employed blast furnace masters from France, and the furnaces were Scottish constructions. According to the book "Pages of Plants History", written based on workers' memoirs, up to the 1890-s "almost all of the bosses were Frenchman"26.

One can assume that the effectiveness of a corporate was determined by economies of scale and a higher level of mechanical engines. However, there is no correlation between labor productivity and size of the enterprise indicators (Table 5). This suggests that it was the managerial practices that determined the business success, above all the other factors. Thus, effectiveness of stock companies as compared to traditional ones can be interpreted as a transfer of Western innovation.

Table 5. Correlation between production per worker and the size of the enterprise in the group of metalworking enterprises in South of Russia

\begin{tabular}{|c|c|c|}
\hline Year & Production & Workers \\
\hline 1908 & 0,20 & 0,10 \\
\hline 1910 & 0,28 & 0,21 \\
\hline 1913 & 0,22 & 0,11 \\
\hline
\end{tabular}

Nevertheless, after 1900, sources suggest a massive trend of replacing foreign managers with Russians ${ }^{27}$. It can be explained by a number of reasons. In 1900-1903, due to the crisis, profits decreased, and owners attempted to cut the high expenses of the management and administration. Employing a Russian manager cost less, so it appeared as a possibility to economize on administrative expenses.

After 1904 one more reason emerged to minimize the presence of foreign managers. The development of the revolutionary movement was accompanied by the spread of xenophobia and anti-capitalism, bursting into direct aggression and even attack against foreign managers and engineers in a number of cases.

In addition, the language barrier with foreign managers was still an actual problem ${ }^{28}$. The increasing qualification and number of Russian en-

${ }^{26}$ Н. Потапчик, П. Панч, Е. Горлова, И.А. Гонимов, Страницъь истории заводов: пробные главы, Харьков 1934, s. 46.

${ }^{27}$ Ch. Wynn, Workers, Strikes, and Pogroms: The Donbass - Dnepr Bend in Late Imperial Russia. 1870-1905, Princeton 1992, s. 21.

${ }^{28}$ В. Пеетерс, Сталь у степу, Київ 2010. 
gineers allowed to replace foreigners with them ${ }^{29}$. As Aleksandr Fenin wrote, "About 60 percent of the coal and 90 percent of the cast iron was produced in plants owned by foreign companies, but by the very beginning of the twentieth century, the overwhelming majority of the managers in the Donbass were Russian engineers. One had to admit that the Russian technical intelligentsia came brilliantly up to this difficult challenge" ${ }^{\prime \prime 3}$.

TRANSFER AND ADAPTATION OF MANAGERIAL MODELS

In addition to the managerial practices, Russia imported new managerial models too from the West. The first attempts to use scientific approach in operations management took place in the late $19^{\text {th }}$ century, initiated within the manufacturing industries by Frederick Taylor in the USA. The main objective was to improve economic efficiency, especially labor productivity. "The remedy from inefficiency lies in systematic management, rather than in searching for some unusual or extraordinary man. In the past the man has been first; in the future the system must be first" said Frederick Taylor ${ }^{31}$. The most important requirement towards scientific management was universality, its applicability "to all kind of human activities, from our simplest individual acts to the work of our great corporations, which call for the most elaborate cooperation" 132 .

Ideas of scientific management began to penetrate into Russia almost immediately after the publication of the founders' first works. By 1917 the main works were translated into Russian ${ }^{33}$. A series of publications was produced by Russian authors, in which they introduced the basic ideas of the founding fathers on scientific management to their readers and interpreted those taking into consideration the Russian conditions. Such works were for example the "Scientific basics of factory management" by Leontiy Levenstern issued in 1913, the "The organization of industrial processing

${ }_{29}^{2}$ Д.А. Сапрыкин, Инженерное образование в России: История, концепциия, перспектива, „Высшее образование в России” 2012, nr 1, s. 128.

${ }^{30}$ A.I. Fenin, op.cit., s. 8.

${ }^{31}$ F. Taylor, The Principles of "Scientific Management", New York-London 1919, s. 7.

${ }^{32}$ Ibidem.

${ }^{33}$ Ф. Тейлор, Искусство резать металхь, С.-Петербург 1909; idem, Административно-техническая организация промышленных предприятий, С.-Петербург 1912; Г.А. Гантт, Современные системы заработной платы и подбор рабочих в связи с доходностью предприятия, С.-Петербург 1913; Ф. Джилбрет [Гильберт], Изучение движений как способ повысить производительность при всякой работе, С.-Петербург 1913; Ф.А. Паркгорст, Практические приемы реогранизации промьииенного предприятия. Административно-техническая библиотека горного инженера А.А. Аевенстерна, С.-Петербург 1914. 
of metals" by Nikolay Charnovskiy in 1914, among some other similar ones $^{34}$.

Finding the ways of labor rationalization was, however, such a burning issue that the discussion quickly ran out of the original framework. Wellknown and widely circulated periodicals such as the "Utro Rossii" (Russia's Morning), the "Russkaya Mysl"" (Russian Thought), the "Birzhevye vedomosti" (Stock Newspaper) journals, and the "Russkiye Vedomosti" (Russian Gazette), the "Lutch" (Ray), the "Pravda" (Truth) newspapers got actively involved into the debate about the nature and prospects of Taylorism in Russia ${ }^{35}$.

In 1913-1914 six issues of the specialized magazine called "FabrichnoZavodskoe Delo" (Factory and Plant matters) were published in St. Petersburg. The journal positioned itself as being [...] devoted to issues about the scientific basis of factory management, administrative and technical organization of industrial enterprises, on methods of increasing labor productivity, promotion of the latest discoveries and inventions in all areas of technology and development of theoretical and practical tasks in connection with calculation of manufactured goods and commercial organization of factories and plants $[\ldots]^{36}$.

The ideas of scientific management met both criticism and support in Russia. Critics were talking about the increasing level of exploitation of workers, about the depersonalization of the human, "enslavement of humankind by the machine" ${ }^{\prime 37}$. In 1913 Vladimir Lenin wrote:

What is the idea of , scientific system"? As the result of this method, three times more labor is squeezed out of the worker during the same nine to ten hour workday; all the worker's strength is unmercifully roused, every bit of nervous and muscular energy is drained from the slave laborer at three times more speed.... Advances in the spheres of technology and science in the capitalist society are but advances in the art of extortion of sweat ${ }^{38}$.

${ }^{34}$ Л.А. Левенстерн, Научные основы заводоуправленияю II. Схема научной организацุии завода, Sankt Petersburg 1913; Н.Ф. Чарновский, Организацзия промышиленных предприятий по обработке металлов, 2-е изд., дополненное, Москва 1914.

${ }^{35}$ А.Л. Дмитриев, А.А. Семенов, Первые шаги американской системы научного менеджмента в дореволюционной России, „Вестник Санкт-Петербургского Университета” 2012, Серия 8, Менеджмент; А.А. Семенов, Появление систем научного менеджмента в России. Научные доклады, nr 6, С.-Петербург 2010.

${ }^{36}$ A.А. Семенов, op.cit., s. 12.

${ }^{37}$ М.В. Бернацкий, Научная организацุия труда, „Коммерческая школа и жизнь” 1913, nr 3; П. Покровский, Система выжимания пота и борьба с ней, „Вестник Европы” 1914, nr 8; В.И. Ленин, Система Тейлора - порабощение человека машиной, [w:] Полное собрание сочинений, Изд. 5-е, Москва 1973.

${ }^{38}$ В.И. Ленин, «Научная» система выжимания пота, [w:] Полное собрание сочинений, Изд. 5-е, Москва 1973, s. 18-19. 
Supporters told that [...] if it was possible to deliver the general scientific foundations, then, based on those, workers and managers would be able to plan who takes what type of work and how to distribute it during the day. It this case we cannot speak about "soulless mechanism". And as the Russian labor productivity is quite low and working conditions are unfavorable, "it is necessary to approach towards a scientific management system, because it leads towards an increase in labor productivity and an active participation of the workers in this process $[\ldots]^{39}$.

However, even supporters of Taylorism admitted, that while in the West the transition to the new systems organization was dictated by the requirements of the technical progress, in Russia this transition is a "piece of fun, "has the character of amateurish approach to innovation". Still, they believed that the time of technological development would come soon even in Russia and then the [...] modern system of plants management will become an essential part of the enterprise, as essential as...machines are $[\ldots]^{40}$.

In general, the majority of Russian publications about scientific management can be characterized as critical. According to the common view, modern approaches of a large-scale administrative reshuffling of work proved to be fruitful only in the case of large, successful companies supplying a sustained massive demand. Scientific contribution of the American innovators is not to be exaggerated ${ }^{41}$.

It is hard to tell how much Taylorism was applied in practice in the South Russian factories. In the contemporary discourse I have encountered the mentioning of three plants where they attempted to adapt the principles of scientific management: two in St. Petersburg and the Nikolaev Shipyard ${ }^{42}$. In his paper, Professor Eduard Koritsky referred to eight enterprises organized according to Taylor's principles before World War I, "whereas in France - only one enterprise" 43 , without, however, specifying all these plants and his sources. Thus, to find out whether there are any more details available about an eventual practical implementation of managerial theories is the task of further archival research.

${ }^{39}$ Н.А. Каблуков, Общеэкономическое и социальное значение системь Тейлора: [Доклад, прочитанный в окт. 1914 г. в Москве в О-ве им. А.И. Чупрова для разработки общественных наук], „Современник” 1915, nr 3, s. 99-103.

${ }^{40}$ И.А. Семенов, Организация заводского хозяйства. (Реферат доклада, читанного в Обществе технологов инж.-технологом И. А. Семеновым), „Записки Императорского Русского технического оьщества" 1912, nr 8-9.

${ }^{41}$ A.A. Семенов, op.cit., s. 29.

${ }^{42}$ В. Постриганев, Увеличение производительности заводских предприятий, „Горнозаводское Дело" 1913, nr 4, s. 6677-6681.

43 Э.Б. Корицкий, Развитие науки о менеджменте в России в 1900-1950-е годы, „Российский журнал менеджмента" 2005, nr 3, s. 129. 
The analysis of the sources confirms that foreign entrepreneurs imported to Russia modern managerial practices and models too besides capital and advanced technologies. Small firms were gradually replaced by modern enterprises, and foreigners played an important part in this process. Foreign entrepreneurs copied the structure and management principles of Western-European companies, and the largest companies employed also foreign engineers, managers and workers.

Taking metallurgy companies as an example, an analysis of the efficiency in the context of ownership structure showed that the key to success did not lie in the size of the enterprise. The operations management - the "Visible hand" - had a significant influence in this respect.

It appears that the role of foreign managers was especially important in the initial stage of the industrialization of Russia. Although there were companies that wanted and could afford to hire foreign managers after 1900 too, foreigners were in general successfully replaced by Russian managers. Many Russian engineers and managers adopted operational managerial practices borrowed from the Western colleagues, and there appears to be no difference in their efficiency from the latter ones as it is reflected by the comparison of data.

There are no direct sources on how and in what extent did the particular managers consider and elaborate on the theories and models of management that evolved in America in the late $19^{\text {th }}$ century. It was present in the public discussion in Russia as reflected by the books and periodicals issued in the period. A possible step forward in the research is to expand it on further groups of archival documents, first and foremost on manufacturing documentation of enterprises stored in Ukrainian, Russian and Western European archives that might contain documents on the practical application of such theories.

\section{BIBLIOGRAFIA:}

Chandler A., The Visible Hand: The Managerial Revolution in American Business, Harvard 1977. Fenin A.I., Coal and Politics in Late Imperial Russia. Memoirs of a Russian Mining Engineer, Illinois 1990.

Gerschenkron A., The Rate of Growth in Russia: The Rate of Industrial Growth in Russia Since 1885, "The Journal of Economic History" 1947, nr 7, s. 144-174.

Gregory P., Before Command: An Economic History of Russia from Emancipation to the First Five-Year Plan, Princeton-New Jersey 1994.

McKay J.P., Pioneers for Profit: Foreign Entrepreneurship and Russian Industrialization. 18851913, Chicago 1970. 
Taylor F., The Principles of "Scientific Management", New York-London 1919.

Wynn Ch., Workers, Strikes, and Pogroms: The Donbass - Dnepr Bend in Late Imperial Russia. 1870-1905, Princeton 1992.

Бернацкий М.В., Научная организацุия труда, „Коммерческая школа и жизнь” 1913, nr 3.

Бовыкин В.И., Грушина Н.Н., Дьяконов И.А., Иностранное предпринимательство и заграничные инвестициии в России: Очерки, Москва 1997.

Бородкин А.И, Валетов Т.Я., Смирнова Ю.Б., Шильникова И.В., «Не рублем единьлм»: Трудовые стилуль рабочих-текстильщиков дореволюицонной России, Москва 2010.

Варзар В.Е., Список фабрик и заводов Европейской России, С.-Петербург 1903.

Варзар В.Е., Список фабрик и заводов Российской Империи, С.-Петербург 1912.

Гантт Г.А., Современные системы заработной платы и подбор рабочих в связи с доходностью предприятия, С.-Петербург 1913.

Джилбрет [Гильберт] Ф., Изучение движений как способ повысить производительность при всякой работе, С.-Петербург 1913.

Дмитриев А.А., Семенов А.А., Первыешагиамериканскойсистемы научногоменеджмента в дореволюиионной России, „Вестник Санкт-Петербургского Университета” 2012, Серия 8, Менеджмент, s. 131-155.

Дмитриев-Мамонов В.А., Указатель действующцх в империи акциионерных предприятий и торговых домов. Сост. по данньлм, извлеч. из материала Отд. торговли, Особ. канцелярии по кредит. части и Деп. ж.-д. дел М-ва фин. Сведения об облигациях сост. Особ. канцелярией по кредит. части. Сведения о торговых домах сост. по офии. данным учреждений М-ва вн. Дел, С.-Петербург 1905.

Друкер П.Ф., Эницклопедия менеджмента, перевод с английского языка, Москва 2004.

Езиоранский И.К., Фабрично-заводские предприятия Российской империи, С.-Петербург 1909.

Каблуков Н.А., Общеэкономическое и социильное значение системы Тейлора: [Доклад, прочитанный в окт. 1914 2. в Москве в О-ве им. А.И. Чупрова для разработки общественных наук], „Современник” 1915, nr 3.

Кандауров Д.П., Фабрично-заводские предприятия Российской империи (исключая Финляндию), Петроград 1914.

Корицкий Э.Б., Развитие науки о менеджменте в России в 1900-1950-е годы, „Российский журнал менеджмента" 2005, nr 3, s. 127-144.

Девенстерн А.А., Научные основы заводоуправленияю II. Схема научной организации завода, С.-Петербург 1913.

Денин В.И., Система Тейлора - порабощение человека машиной, [w:] Полное собрание сочинений, Изд. 5-е, Москва 1973.

Ленин В.И., «Научная» система выжимания пота, [w:] Полное собрание сочинений, Изд. 5-е, Москва 1973.

Паркгорст Ф.А., Практические приемы реогранизации промышленного предприятия. Административно-техническал библиотека горного инженера А.А. Аевенстерна, С.Петербург 1914.

Пеетерс В., Сталь у степу, Київ 2010.

Петров Ю.А., Савинова Е., Золотарев М., Наемные управляющие в России: опыт бизнесэлиты XI-XX веков, Москва 2007.

Покровский П., Система выжимания пота и борьба с ней, „Вестник Европы” 1914, nr 8.

ПостриганевВ., Увеличениепроизводительностизаводскихпредприятий „,Горнозаводское Дело" 1913, nr 4. 
Потапчик Н., Панч П., Горлова Е., Гонимов И.А., Страниц̧ъ истории заводов: пробные главы, Харьков 1934.

Сапрыкин Д.А., Инженерное образование в России: История, концепция, перспектива, „Высшее образование в России” 2012, nr 1.

Семенов А.А., Появление систем научного менеджмента в России. Научные доклады, nr 6, С.-Петербург 2010.

Семенов И.А., Организация заводского хозяйства. (Реферат доклада, читанного в Обществе технологов инж.-технологом И. А. Семеновым), „Записки Императорского Русского технического оьщества" 1912, nr 8-9.

Тейлор Ф., Административно-техническая организация промышленных предприятий, С.-Петербург 1912.

Тейлор Ф., Искусство резать металиь, С.-Петербург 1909.

Чарновский Н.Ф., Организация промышиенных предприятий по обработке металов, 2-е изд., дополненное, Москва 1914.

\section{ABSTRACT:}

The paper presents a research into processes of transfer of managerial models and practices by foreign industrialists to Russia during the period of pre-Soviet industrialization based on an analysis of industrial censuses and further official statistics, as well as unpublished sources housed in local Ukrainian archives.

Key words: industrialization, managerial revolution, scientific management, Russian Empire

\section{NOTA O AUTORZE:}

Wołodymyr Oleksandrowicz Kulikow - docent, kandydat nauk historycznych, zastępca dziekana Wydziału Historycznego ds. naukowych. W kręgu jego zainteresowań znajdują się dzieje gospodarcze południowych guberni Imperium Rosyjskiego w XIX i na początku XX w. e-mail: istfac@univer.kharkov.ua 